\title{
PENGARUH INFLASI, SUKU BUNGA, KURS, COUPON RATE, DAN LIKUIDITAS OBLIGASI TERHADAP HARGA OBLIGASI PEMERINTAH (SURAT UTANG NEGARA) PERIODE 2014-2016
}

\author{
Nur Azizah Rasudu \\ Program Studi Manajemen, Fakultas Ekonomi dan Bisnis Islam \\ Universitas Muhammadiyah Kendari \\ e-mail: nurazizahrasudu@gmail.com
}

\begin{abstract}
ABSTRAK: Penelitian ini bertujuan untuk menganalisis dan mengetahui pengaruh inflasi terhadap harga obligasi, pengaruh suku bunga terhadap harga obligasi, pengaruh kurs terhadap harga obligasi, pengaruh coupon rate terhadap harga obligasi dan pengaruh likuiditas obligasi terhadap harga obligasi. Sampel yang digunakan dalam penelitian ini sebanyak 12 obligasi Pemerintah RI (Surat Utang Negara) seri fixed rate yang terdaftar pada Bursa Efek Indonesia. Metode pengambilan sampel yang digunakan adalah purposive sampling. Metode analisis data menggunakan Analisis Regresi Linear Berganda dengan program SPSS versi 20.0 for windows. Hasil penelitian menunjukkan bahwa suku bunga, kurs dan coupon rate berpengaruh negatif dan signifikan terhadap harga obligasi pemerintah. Disisi lain, inflasi dan likuiditas obligasi berpengaruh positif tapi tidak signifikan terhadap harga obligasi pemerintah.
\end{abstract}

Kata Kunci: Inflasi; Suku Bunga; Kurs; Coupon Rate; Likuiditas Obligasi.

Abstract: This study aims to analyze and determine the effect of inflation on the bond prices, the effect of interest rates on bond prices, the effect of exchange rate on bond prices, the effect of coupon rate on bond prices and the effect of bond liquidity on bond prices. The sample used in this research is 12 bonds of Government of Indonesia (sovereign debt instruments) series of fixed rate listed on Indonesia Stock Exchange. The sampling method used was purposive sampling. Data analysis method used is Multiple Linear Regression Analysis with SPSS version 20.0 for windows. The results showed that the interest rate, exchange rate and coupon rate have a negative and significant effect on the government bond prices. On the other hand, inflation and liquidity of bonds have positive but insignificant effect on government bond prices.

Keywords: Inflation; Interest Rate; Exchange Rate; Coupon Rate; Bond Liquidity.

\section{PENDAHULUAN}

Pasar obligasi memerankan peran penting sebagai salah satu alternatif sumber pembiayaan di masa pertumbuhan ekonomi dunia dewasa kini. Setelah krisis keuangan Asia pada 1997, pemerintah telah memulai secara aktif utilisasi obligasi sebagai sumber utama bagi pembiayaan jangka panjang guna penguatan sistem keuangan suatu negara dan mengurangi potensi guncangan krisis keuangan di masa mendatang (Fabella dan Madhur:2003). Pemerintah Indonesia memandang perlu untuk menutup defisit anggaran belanja pemerintah melalui pinjaman yang bersumber dari dalam negeri. 
Surat Berharga Negara (SBN) merupakan obligasi pemerintah yang dipasarkan dalam suatu pasar keuangan yang mempunyai tujuan untuk membantu pembangunan Indonesia dalam hal meningkatkan pemerataan, pertumbuhan, dan stabilitas ekonomi menuju kesejahteraan masyarakat Indonesia. Miskhin (2008:31) mengemukakan bahwa fungsi utama pasar keuangan adalah mengalirkan dana dari penabung yang mempunyai dana berlebih kepada pembelanja yang dananya terbatas. Surat Berharga Negara (SBN) terdiri atas Surat Utang Negara (SUN) dan Surat Berharga Syariah Negara (SBSN).

Pemerintah setiap tahunnya menerbitkan obligasi untuk pendanaan yang berdampak terhadap peningkatan outstanding (jumlah) obligasi pemerintah di pasar obligasi dalam negeri. Hal tersebut dapat dilihat melalui penerbitan SUN terus meningkat, tahun 2016 pemerintah berhasil menerbitkan dana sebesar Rp.651,85 triliun dengan Rp. 407,89 triliun utang baru. Jumlah penerbitan utang baru (net issuance) tersebut naik +16,56yoy dari tahun 2015 sebesar Rp. 349,94 triliun dan juga tahun 2014 sebesar Rp. 274,39 triliun.

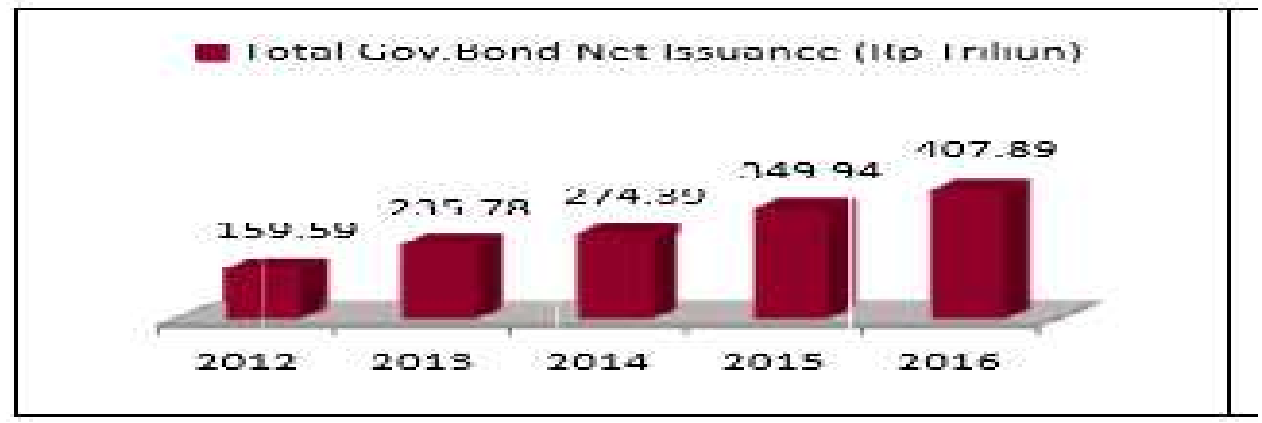

Sumber : Data Sekunder IBPA per 30 Desember 2016

Gambar. 1. Net Issuance Obligasi Pemerintah

Sejalan apresiasi nilai tukar Rupiah, pada triwulan II-2016 pasar surat utang dalam negeri terpantau mengalami penguatan. Imbal hasil (yield) SBN mayoritas tenor turun rata-rata sebesar 37 basis point dibandingkan triwulan sebelumnya. Peningkatan juga dipengaruhi oleh kondisi perekonomian Indonesia yang membaik, diantaranya Bank Indonesia menurunkan $\mathrm{BI}$ rate menjadi 6,5\%, Fitch Rating mengafirmasi peringkat Indonesia pada level invesment grade yaitu BBB-/stable outlook serta menguatnya nilai tukar Rupiah terhadap Dolar AS sebesar Rp 96,- menjadi Rp13.114/USD. Rata-rata volume perdagangan obligasi pemerintah pada tahun 2016 mengalami peningkatan sebesar +9,38\%yoy menjadi Rp13,58 triliun perhari dari sebelumnya sebesar Rp12,24 triliun perhari pada tahun 2015, Rp10,21 pada tahun 2014. Peningkatan juga ditunjukkan dari rata-rata total frekuensi harian yang naik menjadi 817 kali perhari pada tahun 2016 dari 644 kali perhari pada tahun 2015, dan dari 576 kali perhari pada tahun 2014. 
Tabel 1. Volume dan Frekuensi Harian Obligasi Pemerintah

\begin{tabular}{ccc}
\hline Tahun & Volume (Triliun Rupiah/Hari & Frekuensi (Kali/Hari) \\
\hline 2014 & 10,21 & 576 \\
\hline 2015 & 12,42 & 644 \\
\hline 2016 & 13,58 & 817 \\
\hline
\end{tabular}

Sumber : Data IBPA, diolah tahun 2017

Berdasarkan data tersebut, menunjukkan bahwa peningkatan pada iklim investasi bagi investor yang akan menginvestasikan dananya dalam bentuk sekuritas obligasi yang diperdagangkan di bursa efek berdampak pada kinerja pasar obligasi. Namun, adanya peningkatan outstanding (jumlah) obligasi pemerintah di pasar obligasi dalam negeri serta nilai perdagangan dan frekuensi perdagangan obligasi pemerintah, yang perlu diperhatikan oleh investor adalah fluktuasi harga Surat Utang Negara.

Menurut Sudirman (2011:111), penerbitan SUN dalam pemerintahan Indonesia mempunyai potensi yang sangat besar untuk dikembangkan. Ketergantungan pembiayaan luar negeri yang sangat sensitif terhadap naik turunnya nilai tukar mata uang dapat dikurangi dengan penerbitan SUN ini. Selain itu, SUN sebagai alat investasi yang bebas dari resiko gagal bayar, investor SUN mempunyai potensial capital gain apabila melakukan transaksi perdagangan di pasar sekunder. Dengan penerbitan obligasi, pemerintah turut membentuk dan memajukan pasar obligasi di Indonesia. Pemerintah memandang perlu untuk terus-menerus mengembangkan pasar obligasi di Indonesia melalui Direktorat Jenderal Pengelolaan Surat Utang dan Bapepam. Hal ini tercermin dari upaya pemerintah mengembangkan pasar obligasi secara bertahap dengan mempersiapkan aturan hukum dan infrastruktur penunjang pasar untuk mencapai kondisi pasar obligasi yang likuid dan efisien. Pemerintah Indonesia dalam beberapa tahun terakhir berupaya untuk meningkatkan partisipasi masyarakat dalam pembiayaan pembangunan negara Indonesia melalui mekanisme APBN melalui penerbitan SUN kepada masyarakat.

Salah satu faktor penentu apakah investor akan tertarik berinvestasi pada obligasi adalah faktor inflasi. Ketika inflasi sedang naik, harga obligasi turun. Saat inflasi menurun, harga obligasi naik. Itu karena kenaikan inflasi mengikis daya beli dari apa yang akan didapatkan atas investasi. Peningkatan inflasi secara relatif merupakan sinyal negatif bagi pemodal di pasar modal. Selain inflasi, salah satu yang mempengaruhi harga obligasi adalah tingkat suku bunga yang diberikan kepada investor. Apabila tingkat suku bunga deposito naik maka harga obligasi akan turun, karena investor yang rasional akan memilih investasi yang bebas resiko dengan return yang sama. Menurut Longstaff dan Schwartz (1993) pada jurnal penelitiannya menyatakan bahwa suku bunga mempengaruhi harga obligasi secara signifikan. Bila suku bunga rendah maka investor akan tertarik berinvestasi pada obligasi.

Kurs merupakan nilai tukar mata uang suatu negara terhadap nilai mata uang negara lain. Dalam sisi lain dengan adanya ekspetasi kurs yang positif membuat nilai perusahaan akan mengalami kenaikan sehingga terjadi peningkatan harga sekuritas yakni saham dan obligasi. Nilai tukar rupiah terhadap mata uang lainnya sangat berpengaruh bagi perusahaan yang ingin melakukan investasi, karena apabila pasar 
valuta asing lebih menarik dari pada pasar modal maka investor akan beralih kepada pasar valuta asing, sehingga perubahan kurs (nilai tukar) akan berpengaruh terhadap harga obligasi di pasar modal.

Dalam menerbitkan obligasi akan ditentukan oleh tingkat kupon obligasi (coupon rate). Kupon merupakan salah satu faktor yang dipertimbangkan oleh investor dalam berinvestasi pada sekuritas obligasi. Semakin tinggi kupon yang ditawarkan oleh suatu obligasi maka semakin besar permintaan akan obligasi tersebut, sehingga menyebabkan harga obligasi cenderung meningkat. Investor tertarik membeli obligasi tersebut karena dianggap akan memberikan pengembalian yang lebih besar. Harga obligasi juga dipengaruhi oleh likuiditas obligasi itu sendiri, dimana obligasi yang memiliki likuiditas tinggi akan menyebabkan harga pasar obligasi stabil bahkan meningkat. Sebaliknya apabila likuiditas obligasi rendah, maka harga pasar obligasi akan melemah. Oleh karena itu investor pada saat membeli obligasi akan cenderung memilih obligasi yang likuid yaitu obligasi yang sering diperdagangkan investor di pasar obligasi.

Kerangka konseptual dalam penelitian seperti tampak gambar di bawah ini:

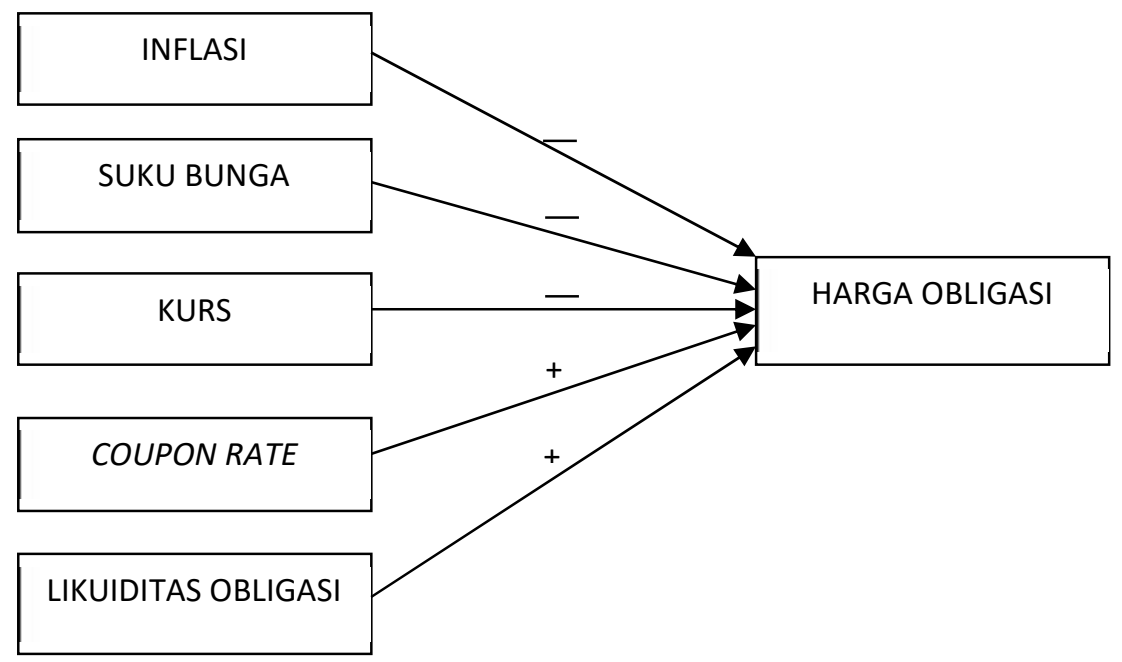

Sumber : Ichsan, dkk (2013), Sukanto dan Widaryanti (2015), Longstaff dan Schwartz (1993), Sukanto (2009), Juhartono (2010), Haryanto (2013) dan Dewi, dkk (2016), Sukanto (2009), Hadian (2013), Haryanto (2013) dan Dewi, dkk (2016) Damena, dkk (2013) dan Dewi, dkk (2016), Krisnilasari (2007) dan Daryono (2016).

\section{Gambar 2. Kerangka Konseptual}

Berdasarkan kerangka konsep pada gambar 2 maka hipotesis yang diajukan dalam penelitian ini sebagai berikut:

\section{Pengaruh Inflasi Terhadap Harga Obligasi}

Inflasi adalah kenaikan harga secara umum, atau Inflasi dapat juga dikatakan sebagai penurunan daya beli uang. Makin tinggi kenaikan harga makin turun nilai uang. Menurut teori investasi, jika inflasi naik maka daya beli turun, orang lebih mengutamakan konsumsi daripada investasi. Investasi turun sehingga daya beli terhadap obligasi juga turun. Tingkat inflasi berpengaruh negatif pada tingkat investasi hal ini disebabkan karena tingkat inflasi yang tinggi akan meningkatkan resiko proyek- 
proyek investasi dan dalam jangka panjang inflasi yang tinggi dapat mengurangi ratarata masa jatuh pinjam modal serta menimbulkan distrosi informasi tentang hargaharga relatif. Jika inflasi makin tinggi, akan mengakibatkan purchasing power menurun sehingga likuiditas obligasi terpengaruh hingga harganya cenderung turun.

Jika inflasi meningkat maka harga obligasi akan naik, hal ini sejalan dengan hasil penelitian Ichsan, dkk (2013) bahwa inflasi berpengaruh positif terhadap obligasi. Pada saat inflasi mencapai titik tertinggi maka harga obligasi diestimasi akan mencapai titik terendah yang tentunya akan menjadi peluang bagi investor untuk berinvestasi terutama pada obligasi yang memiliki ekspektasi imbal balik yang lebih tinggi. Hal ini dikarenakan setelah mencapai titik puncak, suku bunga akan turun dan memberikan dampak positif terhadap harga obligasi. Berdasarkan konsep dan temuan empiris tersebut diatas, maka hipotesis pertama yang diajukan dalam penelitian ini adalah :

$\mathrm{H}_{1}$ : Inflasi berpengaruh negatif signifikan terhadap harga obligasi

2. Pengaruh Suku Bunga Terhadap Harga Obligasi

Suku bunga adalah jumlah bunga yang dibayarkan per unit waktu. Dengan kata lain, masyarakat harus membayar peluang untuk meminjam uang. Biaya untuk meminjam uang di ukur dalam Rupiah atau Dollar per tahun untuk setiap Rupiah atau Dollar yang dipinjam adalah Suku Bunga. Menurut Boediono (1996:76), Suku bunga adalah harga yang harus di bayar apabila terjadi pertukaran antara satu Rupiah sekarang dan satu Rupiah nanti.

Jogiyanto (2009: 174) menyatakan dengan meningkatnya suku bunga, maka tabungan akan semakin menarik karena memberikan bunga tabungan yang tinggi, sehingga investor akan menjual obligasinya dan mengalihkan hasilnya ke tabungan dengan bunga yang lebih tinggi, akibatnya penawaran (supply) obligasi akan meningkat. Dengan meningkatnya penawaran, obligasi akan ditawarkan dengan diskon sehingga menyebabkan harga obligasi melemah, begitu pula sebaliknya. Apabila tingkat suku bunga deposito naik maka harga obligasi akan turun, karena investor yang rasional akan memilih investasi yang bebas resiko dengan return yang sama.

Tandelilin (2010) menyatakan bahwa tingkat bunga yang tinggi akan menyebabkan return yang diisyaratkan dari suatu investasi akan meningkat. Menurut informasi dari BAPEPAM (2011) nilai suatu obligasi bergerak berlawanan arah dengan perubahan suku bunga secara umum. Jika suku bunga secara umum cenderung turun, maka nilai atau harga obligasi akan meningkat, karena para investor cenderung untuk berinvestasi pada obligasi. Sementara itu, jika suku bunga secara umum cenderung meningkat, maka nilai atau harga obligasi akan turun, karena para investor cenderung untuk menanamkan uangnya di bank.

Suku bunga merupakan salah satu variabel yang mempengaruhi harga pasar obligasi. Jika suku bunga SBI lebih tinggi dari pada tingkat kupon yang diterima investor maka investor akan lebih tertarik menanamkan dananya dalam bentuk deposito dengan pendapatan atau return yang lebih tinggi serta risiko yang lebih rendah dibanding berinvestasi pada obligasi, hal tersebut akan berdampak pada banyaknya penawaran obligasi oleh investor dengan asumsi permintaan tetap, maka akan berdampak pada penurunan harga pasar obligasi.Hal tersebut sejalan dengan hasil Dewi, dkk (2016), juga hasil penelitian Longstaff dan Schwartz (1993), Sukanto (2009), Juhartono (2010) dan Haryanto (2013) menyatakan bahwa suku bunga berpengaruh negatif signifikan 
terhadap harga obligasi. Berdasarkan konsep dan temuan empiris tersebut diatas, maka hipotesis kedua dalam penelitian ini adalah:

$\mathrm{H}_{2} \quad$ : Suku bunga berpengaruh negatif signifikan terhadap harga obligasi

3. Pengaruh Kurs Terhadap Harga Obligasi

Nilai tukar suatu mata uang atau kurs adalah nilai tukar mata uang suatu negara terhadap negara asing lainya (Thobarry, 2009). Naik turunnya nilai tukar mata uang atau kurs valuta asing bisa terjadi dengan berbagai cara, yakni bisa dengan cara dilakukan secara resmi oleh pemerintah suatu negara yang menganut sistem managed floating exchange rate, atau bisa juga karena tarik menariknya kekuatan-kekuatan penawaran dan permintaan di dalam pasar (market mechanism). Menurut (Thobarry, 2009:46) bahwa perubahan nilai tukar mata uang tersebut bisa terjadi karena empat hal, yaitu inflasi, jumlah uang beredar, pendapatan nasional dan posisi neraca pembayaran internasional Indonesia.

Henderson et al (2004) menjelaskan bahwa risiko nilai tukar (kurs) berkaitan dengan obligasi asing atau sovereign bond tersebut terjadi karena obligasi mata uang asing dibayarkan dengan mata uang domestik yang tentu saja ada spread atau nilai tukarnya. Ogawa dan Shimizu (2004) yang menganalisis keuantungan dan kerugian pemilihan mata uang untuk menerbitkan obligasi internasional menemukan adanya trade off dari penerbit obligasi antara risiko nilai tukar dan likuiditas dalam pemilihan denominasi kurs dari terbitan obligasi di Asia Timur, dimana risiko nilai tukar terjadi ketika membaiknya pasar obligasi regional. Hasil penelitian mereka juga menemukan bahwa risiko nilai tukar lebih kecil dalam hal menerbitkan obligasi mata uang dolar.

Nilai tukar mata uang (exchange rate) mempengaruhi permintaan obligasi di Indonesia. Nilai tukar mata uang rupiah terhadap beberapa mata uang asing yang belum stabil mempengaruhi jumlah permintaan obligasi. Jika kurs rupiah terhadap USD turun, maka investasi obligasi meningkat.

Hasil penelitian Sukanto (2009), Hadian (2013), Haryanto (2013) dan Dewi, dkk (2016) menyatakan bahwa nilai tukar atau kurs berpengaruh negatif signifikan terhadap harga obligasi. Sementara hasil penelitian Ichsan, dkk (2013) menyatakan bahwa nilai tukar (kurs) berpengaruh positif signifikan terhadap harga obligasi. Berdasarkan konsep dan temuan empiris diatas, maka hipotesis ketiga yang diajukan dalam penelitian ini adalah :

$\mathrm{H}_{3}$ : Kurs berpengaruh negatif signifikan terhadap harga obligasi

\section{Pengaruh Coupon Rate Terhadap Harga Obligasi}

Kupon adalah berupa pendapatan suku bunga yang diterima oleh pemegang obligasi atas perjanjian dengan penerbit obligasi tersebut. Kupon biasanya dilakukan pembayaran secara periode tertentu menurut (Rahardjo, 2003). Coupon rate digunakan untuk mengukur rata-rata tingkat keuntungan yang diterima oleh pemegang obligasi tersebut dalam setahun selama jangka waktu investasi obligasi dan hasil keuntungannya diterima oleh investor setiap tiga bulan sekali sedangkan time to maturity tingkat hasil yang akan pemodal peroleh jika membeli sebuah obligasi yang berpatokan pada harga pasar dan memegangnya sampai dengan jatuh tempo.

Tingkat kupon yang meningkat menyebabkan harga pasar obligasi semakin meningkat, karena pengaruh tingkat kupon terhadap harga obligasi adalah positif. 
Valckx (2004) dan Mardika (2008) mengemukakan bahwa tingkat kupon obligasi sangat berpengaruh terhadap harga obligasi. Racette dan Lawellen (1995) yang menggunakan pendekatan matematis dalam kajiannya tentang hubungan tingkat kupon terhadap harga obligasi, menyimpulkan bahwa tingkat kupon berpengaruh positif terhadap harga obligasi. Penelitian Damena, dkk (2013) dan Dewi, dkk (2016) menyatakan bahwa coupon rate berpengaruh positif signifikan terhadap harga pasar obligasi. Berdasarkan konsep dan temuan empiris tersebut diatas, maka hipotesis keempat yang diajukan dalam penelitian ini adalah :

\section{$\mathrm{H}_{4}$ : Coupon rate berpengaruh positif signifikan terhadap harga obligasi}

\section{Pengaruh Likuiditas Obligasi Terhadap Harga Obligasi}

Obligasi yang likuid adalah obligasi yang banyak beredar di kalangan pemegang obligasi serta sering diperdagangkan oleh investor di pasar obligasi. Apabila obligasi yang dibeli mempunyai likuiditas cukup tinggi maka harga obligasi tersebut cenderung stabil dan meningkat. Tetapi apabila likuiditas obligasi tersebut rendah, harga obligasi cenderung melemah. Menurut Krisnilasari (2007) menyatakan bahwa obligasi yang likuid merupakan obligasi yang mudah diperjualbelikan di pasar modal.

Penelitian Chakravarty dan Sarkar (1999), Yuan (2001) dan Facero et.al (2008) bahwa likuiditas obligasi sangat berpengaruh terhadap harga obligasi. Semakin tinggi likuiditas obligasi akan menyebabkan obligasi lebih menarik, sehingga dapat meningkatkan harga obligasi. Penelitian Krisnilasari (2007) bahwa likuiditas obligasi berpengaruh positif signifikan terhadap perubahan harga obligasi. Daryono (2016) menyatakan liquiditas obligasi berpengaruh positif signifikan terhadap harga Surat Utang Negara. Berdasarkan konsep dan temuan empiris tersebut diatas maka hipotesis kelima yang diajukan dalam penelitian ini adalah :

$\mathrm{H}_{5}$ : Likuiditas obligasi berpengaruh positif signifikan terhadap harga obligasi

\section{METODE PENELITIAN \\ Hasil Uji Data Screening \\ Uji Normalitas}

Screening terhadap normalitas data dilakukan untuk setiap analisis multivariate, khususnya jika tujuannya adalah inferensi. Jika terdapat normalitas, maka residual akan terdistribusi secara normal dan independen, dengan cara mendeteksi normalitas adalah lewat pengamatan nilai residual.

Tabel 2. Uji Normalitas Data (One-Sample Kolmogorov-Smirnov Test)

\begin{tabular}{|c|c|c|c|c|c|c|c|}
\hline & & Inflasi & Suku Bunga & Kurs & $\begin{array}{l}\text { Coupon } \\
\text { Rate }\end{array}$ & $\begin{array}{l}\text { Likuiditas } \\
\text { Obligasi }\end{array}$ & Harga.Obligasi \\
\hline $\mathrm{N}$ & & 36 & 36 & 36 & 36 & 36 & 36 \\
\hline \multirow[b]{2}{*}{ Normal Parameters ${ }^{a, b}$} & Mean & 1.63795 & 1.92403 & 2.55199 & 2.14908 & 1.92068 & 4.59392 \\
\hline & $\begin{array}{l}\text { Std. } \\
\text { Deviation }\end{array}$ & .348646 & .056674 & .062871 & .076961 & .256860 & .035972 \\
\hline \multirow{3}{*}{$\begin{array}{l}\text { Most Extreme } \\
\text { Differences }\end{array}$} & Absolute & .209 & .182 & .173 & .176 & .101 & .120 \\
\hline & Positive & .125 & .143 & .098 & .082 & .075 & .109 \\
\hline & Negative & -.209 & -.182 & -.173 & -.176 & -.101 & -.120 \\
\hline Kolmogorov-Smirnov Z & & 1.251 & 1.093 & 1.039 & 1.054 & .604 & .720 \\
\hline Asymp. Sig. (2-tailed) & & .087 & .183 & .230 & .217 & .859 & .678 \\
\hline
\end{tabular}


Berdasarkan Tabel 2 tersebut menunjukkan bahwa hasil uji Kolmogorov-Smirnov memberikan nilai Asymp-Sig(2-tailed)> 0,05, sehingga dengan demikian dapat disimpulkan bahwa data semua variabel dalam penelitian ini berdistribusi normal.

\section{Uji Autokorelasi}

Uji autokorelasi adalah untuk melihat apakah terjadi korelasi antara suatu periode $t$ dengan periode sebelumnya ( $t-1)$. Hasil uji autokorelasi selanjutnya dapat dilihat pada tabel hasil pengolahan data melalui SPSS sebagai berikut :

Tabel 3. Uji Autokorelasi (Model Summary ${ }^{b}$ )

\begin{tabular}{lrrrrr}
\hline Model & R & R Square & $\begin{array}{c}\text { Adjusted R } \\
\text { Square }\end{array}$ & $\begin{array}{r}\text { Std. Error of } \\
\text { the Estimate }\end{array}$ & \multicolumn{1}{c}{$\begin{array}{c}\text { Durbin- } \\
\text { Watson }\end{array}$} \\
\hline 1 & $.749^{\mathrm{a}}$ & .561 & .487 & .025753 & 1.133 \\
\hline
\end{tabular}

a. Predictors: (Constant), Likuiditas, Kurs, Coupon, Sukubunga, Inflasi

b. Dependent Variable: Harga

Berdasarkan Tabel 3. angka Durbin-Watson dalam penelitian ini menunjukkan 1,133 berada diantara -2 dan +2 yang berarti tidak ada autokorelasi.

\section{Hasil Analisis Regresi Berganda}

Analisis regresi linier berganda adalah suatu prosedur statistik untuk mengestimasi satu atau lebih variabel independen $(\mathrm{X})$ terhadap variabel dependen $(\mathrm{Y})$. Persamaan regresi linier berganda dalam penelitian ini dihitung dengan menggunakan bantuan program SPSS 20 for windows. Hasil regresi linear berganda ditampilkan pada tabel berikut :

Tabel 4. Analisis Regresi Linear Berganda Coefficients ${ }^{a}$

\begin{tabular}{|c|c|c|c|c|c|c|}
\hline \multirow{2}{*}{\multicolumn{2}{|c|}{ Model }} & \multicolumn{2}{|c|}{$\begin{array}{l}\text { Unstandardized } \\
\text { Coefficients }\end{array}$} & \multirow{2}{*}{$\begin{array}{c}\text { Standardized } \\
\text { Coefficients } \\
\text { Beta }\end{array}$} & \multirow[t]{2}{*}{$\mathrm{t}$} & \multirow[t]{2}{*}{ Sig. } \\
\hline & & B & Std. Error & & & \\
\hline \multirow{6}{*}{1} & (Constant) & 6.883 & .519 & & 13.258 & .000 \\
\hline & Inflasi & .008 & .005 & .565 & 1.523 & .138 \\
\hline & Suku bunga & -.681 & .194 & -1.171 & -3.508 & .001 \\
\hline & Kurs & -.185 & .076 & -.324 & -2.452 & .020 \\
\hline & Coupon & -.217 & .061 & -.438 & -3.584 & .001 \\
\hline & Likuiditas & .002 & .025 & .016 & .093 & .927 \\
\hline
\end{tabular}

a. Dependent Variable: Harga

$\mathrm{Y}=0,565 \mathrm{X}_{1}-1,171 \mathrm{X}_{2}-0,324 \mathrm{X}_{3}-0,438 \mathrm{X}_{4}+0,016 \mathrm{X}_{5}$

Koefisien $\mathrm{X}_{1}=0,565$ artinya inflasi $\left(\mathrm{X}_{1}\right)$ berpengaruh positif tapi tidak signifikan terhadap harga obligasi (Y). Nilai koefisien inflasi positif menunjukkan bahwa peningkatan atau penurunan inflasi tidak dapat diikuti penurunan atau peningkatan harga obligasi. Koefisien $X_{2}=-1,171$ artinya suku bunga $\left(X_{2}\right)$ berpengaruh negatif signifikan terhadap harga obligasi $(Y)$. Nilai koefisien suku bunga negatif menunjukkan bahwa kenaikan suku bunga akan diikuti penurunan harga obligasi. Koefisien $X_{3}=-0,324$ 
artinya kurs $\left(\mathrm{X}_{3}\right)$ berpengaruh negatif signifikan terhadap harga obligasi $(\mathrm{Y})$. Nilai koefisien kurs negatif menunjukkan bahwa kenaikan kurs akan diikuti penurunan harga obligasi. Koefisien $\mathrm{X}_{4}=-0,438$ artinya coupon rate $\left(\mathrm{X}_{4}\right)$ berpengaruh negatif signifikan terhadap harga obligasi (Y).

Nilai koefisien coupon rate negatif menunjukkan bahwa penurunan coupon rate akan diikuti penurunan harga obligasi. Koefisien $X_{5}=0,016$ artinya likuiditas obligasi $\left(X_{5}\right)$ berpengaruh positif tapi tidak signifikan terhadap harga obligasi $(Y)$. Nilai koefisien likuiditas obligasi positif, namun menunjukkan bahwa kenaikan atau penurunan likuiditas obligasi tidak dapat diikuti peningkatan atau penurunan harga obligasi.

\section{Hasil Uji Hipotesis}

Pengujian melalui uji t dilakukan dengan membandingkan t hitung dengan t tabel atau melihat nilai $t$ sig pada taraf signifikan $(p)=5 \%$, dengan kriteria sebagai berikut: 1).Jika nilai nilai t sig $>0,05$ (taraf kepercayaan $\alpha=5 \%$ ), maka Ho diterima. 2).Jika nilai nilai nilai t sig $<0,05$ (taraf kepercayaan $\alpha=5 \%$ ), maka Ho ditolak yang berarti menerima Ha.

Berdasarkan dari kriteria pengujian hipotesis tersebut diatas, maka dapat diuraikan sebagai berikut:

1. Uji Hipotesis Pengaruh Inflasi $\left(\mathrm{X}_{1}\right)$ Terhadap Harga Obligasi $(\mathrm{Y})$

Berdasarkan hasil perhitungan statistik menggunakan SPSS 20 (tabel 5.4) menunjukkan bahwa nilai probabilitas $t$ sig $(0,138)$ lebih besar dari 0,05 (taraf kepercayaan $\alpha=95 \%$ ), maka Ho diterima dan Ha ditolak yang berarti inflasi berpengaruh positif tapi tidak signifikan terhadap harga obligasi Pemerintah RI (Surat Utang Negara).

2. Uji Hipotesis Pengaruh Suku Bunga $\left(\mathrm{X}_{2}\right)$ Terhadap Harga Obligasi $(\mathrm{Y})$

Berdasarkan hasil perhitungan statistik (tabel 5.4) menunjukkan nilai probabilitas t sig $(0,001)$ jauh lebih kecil dari 0,05 (taraf kepercayaan $\alpha=95 \%$ ), maka Ho ditolak dan Ha diterima yang berarti suku bunga berpengaruh negatif signifikan terhadap harga obligasi Pemerintah RI (Surat Utang Negara).

3. Uji Hipotesis Pengaruh Kurs $\left(\mathrm{X}_{3}\right)$ Terhadap Harga Obligasi $(\mathrm{Y})$

Berdasarkan hasil perhitungan statistik (tabel 5.4) diperoleh nilai probabilitas t sig $(0,020)$ lebih kecil dari 0,05 (taraf kepercayaan $\alpha=95 \%$ ), maka Ho ditolak dan $\mathrm{Ha}$ diterima yang berarti kurs berpengaruh negatif signifikan terhadap harga obligasi Pemerintah RI (Surat Utang Negara).

4. Uji Hipotesis Pengaruh Coupon Rate $\left(\mathrm{X}_{4}\right)$ Terhadap Harga Obligasi $(\mathrm{Y})$

Berdasarkan hasil perhitungan statistik (tabel 5.4) diperoleh nilai probabilitas t sig $(0,001$ ) lebih kecil dari 0,05 (taraf kepercayaan $\alpha=95 \%$ ), maka Ho ditolak dan $\mathrm{Ha}$ diterima yang berarti coupon rate berpengaruh negatif signifikan terhadap harga obligasi Pemerintah RI (Surat Utang Negara).

5. Uji Hipotesis Pengaruh Likuiditas Obligasi $\left(\mathrm{X}_{5}\right)$ Terhadap Harga Obligasi $(\mathrm{Y})$

Berdasarkan hasil perhitungan statistik (tabel 5.4) diperoleh nilai probabilitas t sig $(0,927)$ lebih besar dari 0,05 (taraf kepercayaan $\alpha=95 \%$ ), maka Ho diterima dan $\mathrm{Ha}$ ditolak yang berarti likuiditas obligasi berpengaruh positif tapi tidak signifikan terhadap harga obligasi Pemerintah RI (Surat Utang Negara). 
Berdasarkan tujuan yang ingin dicapai dalam penelitian ini, maka rancangan penelitian ini bersifat explanatory. Menurut Solimun (2002:63) suatu penelitian yang bersifat Explanatory umumnya bertujuan untuk menjelaskan kedudukan variabelvariabel yang akan diteliti serta hubungan atau pengaruh antara variabel yang satu dengan variabel yang lain. Adapun tipologi penelitian yang bersifat explanatory dalam penelitian ini yaitu pengaruh motivasi kerja, lingkungan kerja dan disiplin kerja terhadap kinerja perawat.

Populasi merupakan wilayah generalisasi yang terdiri dari objek atau subjek yang memiliki kualitas atau karakteristik tertentu yang ditetapkan oleh peneliti untuk dipelajari dan kemudian ditarik kesimpulan (Sugiyono, 2012: 115). Populasi dalam penelitian ini adalah seluruh obligasi seri fixed rate Pemerintah RI berjumlah 38 obligasi.

Sampel adalah sebagian dari populasi yang terdiri atas sejumlah anggota yang dipilih dari populasi (Sugiyono, 2012: 116). Metode pengambilan sampel menggunakan metode non probability sampling yakni purposive sampling. Dari jumlah populasi tersebut obligasi yang menjadi sampel yang digunakan dalam penelitian ini adalah sebanyak 12 obligasi dengan memenuhi kriteria sebagai berikut :

Tabel 5. Seleksi Sampel berdasarkan Kriteria

\begin{tabular}{lc}
\hline \multicolumn{1}{c}{ Keterangan } & Jumlah Seri \\
\hline Obligasi yang aktif beredar di pasar sekunder & 54 \\
\hline $\begin{array}{l}\text { Obligasi yang aktif beredar di pasar sekunder tetapi membayar } \\
\text { kupon dengan variabel rate }\end{array}$ & $(13)$ \\
\hline Obligasi Ritel Indonesia yang aktif beredar di pasar sekunder & $(3)$ \\
\hline $\begin{array}{l}\text { Obligasi yang aktif diperdagangkan di pasar sekunder dan } \\
\text { membayar kupon rate tetap selama tahun 2014-2016 }\end{array}$ & 38 \\
\hline $\begin{array}{l}\text { Obligasi yang paling aktif diperdagangkan di pasar dan paling } \\
\text { likuid dari sisi frekuensi selama tahun 2014-2016 }\end{array}$ & 12 \\
\hline
\end{tabular}

Jenis data yang digunakan dalam penelitian ini adalah data kuantitatif. Menurut Sugiyono (2012:13), data kuantitatif adalah data yang berbentuk angka. Adapun data dalam penelitian ini yaitu inflasi, suku bunga, kurs, coupon rate, likuiditas obligasi dan harga obligasi dari tahun 2014 sampai tahun 2016.

Adapun sumber data dalam penelitian ini adalah sumber data sekunder. Menurut Sugiyono (2012:14) bahwa data sekunder adalah data yang bukan diusahakan sendiri pencatatanya dan pengumpulanya oleh peneliti namun dilakukan oleh pihak lain. Data sekunder penelitian ini diperoleh dari situs resmi Bursa Efek Indonesia melalui situs www.bei.co.id, www.IBPA.co.id www.bi.go.id dan http://pusatdata.kontan.co.id

Metode pengumpulan data yang digunakan dalam penelitian ini adalah metode observasi non partisipan. Metode observasi non partisipan menurut Sugiyono (2012:204) adalah metode observasi dimana peneliti tidak terlibat secara langsung dan hanya sebagai pengamat independen. Peneliti memperoleh data dengan cara mengamati, mencatat, menganalisis dan selanjutnya dapat membuat suatu kesimpulan dari data yang diamati. Metode analisis yang digunakan dalam penelitian ini 
menggunakan metode data screening, metode data outlier, analisis regresi linear berganda dan pengujian hipotesis atau uji t.

Dalam analisis regresi, selain mengukur kekuatan hubungan antara dua variabel atau lebih, juga menunjukkan arah hubungan antara variabel dependen dengan variabel independen (Ghozali, 2011:96). Analisis regresi linier berganda adalah suatu prosedur statistik untuk mengestimasi satu atau lebih variabel independen $(X)$ terhadap variabel dependen (Y). Adapun rumus multiple regresinya adalah sebagai berikut: $Y=a+\beta_{1} X_{1}+$ $\beta_{2} X_{2}+\beta_{3} X_{3}+\beta_{4} X_{4}+\beta_{5} X_{5}+e$

Dimana: $Y=$ Harga obligasi; $X_{1}=$ Inflasi; $X_{2}=$ Suku bunga; $X_{3}=$ Kurs; $X_{4}=$ Coupon rate; $X_{5}=$ Likuiditas obligasi; $a=$ Konstanta regresi berganda; $\beta_{1}, \beta_{2} \ldots . .=$ Koefisien regresi; $e=$ error (variabel bebas lain diluar model regresi).

Persamaan regresi linier berganda dalam penelitian ini dihitung dengan menggunakan bantuan program SPSS 20 for windows. Jika koefisien $\beta$ bernilai positif maka dapat dikatakan terdapat hubungan yang searah antara variabel bebas dengan variabel terikatnya, sehingga setiap kenaikan variabel bebas akan mengakibatkan kenaikan pada variabel terikat.

\section{HASIL PENELITIAN DAN PEMBAHASAN}

Berdasarkan hasil pengujian hipotesis (uji t) yang diolah menggunakan SPSS 20 for windows pada tabel 4 menunjukkan bahwa variabel suku bunga, kurs, dan coupon rate berpengaruh negatif signifikan terhadap harga obligasi, disisi lain variabel inflasi dan likuiditas obligasi berpengaruh positif tetapi tidak signifikan terhadap harga obligasi. Dengan demikian dapat disimpulkan bahwa hanya dua variabel yang mendukung hipotesis dalam penelitian ini.

Hipotesis pertama dalam penelitian ini menyatakan bahwa inflasi berpengaruh negatif signifikan terhadap harga obligasi. Berdasarkan hasil pengujian hipotesis, diketahui bahwa nilai koefisien inflasi sebesar 0,565 dengan signifikansi sebesar 0,138 lebih besar dari $\alpha=0,05$. Hal ini menunjukkan bahwa $\mathrm{H}_{1}$ ditolak. Koefisien inflasi positif menunjukkan bahwa kondisi inflasi saat ini rendah dan stabil. Inflasi dan harga obligasi memiliki hubungan yang lemah sebesar 5,65 persen, sehingga memiliki hubungan yang tidak signifikan. Apabila inflasi terjadi peningkatan atau penurunan tidak dapat diikuti penurunan atau peningkatan harga obligasi. Hasil penelitian ini tidak sesuai dengan hipotesis yang diajukan, namun sesuai dengan hasil penelitian yang dilakukan oleh Sukanto (2009) menyatakan bahwa inflasi tidak berpengaruh signifikan terhadap harga obligasi.

Inflasi yang tidak berpengaruh signifikan terhadap harga obligasi masih tergolong inflasi yang rendah dan stabil. Menurut Putong (2002:260), inflasi rendah yaitu inflasi yang besarnya kurang dari $10 \%$. Inflasi yang rendah dan stabil merupakan prasyarat mendasar dalam mencapai pertumbuhan ekonomi secara berkelanjutan dan kesejahteraan masyarakat (Hutabarat:2005). Dengan adanya inflasi yang ringan, mempunyai pengaruh positif yang dapat mendorong perekonomian, yaitu meningkatnya pendapatan nasional dan membuat orang bergairah untuk bekerja, menabung dan mengadakan investasi.

Hasil penelitian ini mengidentifikasikan bahwa para investor atau pembeli obligasi Pemerintah RI (Surat Utang Negara) perlu memperhatikan kondisi inflasi rendah 
dan stabil dalam negeri yang tidak berperan dalam menentukan naik atau turunnya harga obligasi. Hal ini menimbulkan ekspektasi positif bagi perekonomian Indonesia secara umum serta bagi pasar obligasi secara khusus pasar obligasi Pemerintah.

Hipotesis kedua dalam penelitian ini menyatakan bahwa suku bunga berpengaruh negatif signifikan terhadap harga obligasi. Berdasarkan hasil pengujian hipotesis, diketahui bahwa nilai koefisien suku bunga sebesar-1,171 dan signifikansi sebesar 0,001 lebih kecil dari $\alpha=0,05$. Hal ini menunjukkan bahwa $\mathrm{H}_{2}$ diterima. Suku bunga memiliki hubungan yang negatif dan signifikan dengan harga obligasi dengan keeratan hubungan yang sangat kuat. Artinya suku bunga sangat mempengaruhi fluktuasi harga obligasi. Suku bunga merupakan acuan yang bebas risiko memiliki peranan penting dalam memproyeksi pergerakan harga obligasi pemerintah. Hasil penelitian ini mengidentifikasikan bahwa para investor atau pembeli obligasi Pemerintah RI (Surat Utang Negara) perlu memperhatikan suku bunga sebagai faktor yang mempengaruhi fluktuasi harga obligasi.

Hasil penelitian ini mendukung teori yang dikemukakan oleh Fabozzi (2004) yang menyatakan bahwa tipikal harga obligasi akan berubah berlawanan arah dari perubahan tingkat bunga, jika tingkat bunga naik maka harga obligasi akan berubah, sebaliknya jika tingkat bunga jatuh maka harga obligasi akan naik. Brigham dan Houston (2006) yang menyatakan bahwa harga obligasi akan meningkat apabila tingkat suku bunga yang berlaku turun, diakibatkan karena adanya interest rate risk yaitu risiko penurunan harga obligasi yang diakibatkan karena kenaikan tingkat suku bunga. Kemudian teori yang dikemukakan oleh Jogiyanto (2009: 174) yang menyatakan bahwa hubungan antara suku bunga dengan harga obligasi adalah berlawanan arah yaitu semakin meningkatnya (menurunnya) suku bunga, semakin menurunnya (menaiknya) harga obligasi. Hal ini menunjukkan hubungan negatif antara suku bunga dengan harga obligasi.

Sebaliknya dengan menurunnya suku bunga, maka tabungan akan semakin kurang menarik karena memberikan bunga tabungan yang menurun, akibatnya investor akan menarik tabungannya dan mengalihkannya ke obligasi dengan bunga yang lebih tinggi. Akibatnya permintaan (demand) obligasi meningkat dan karena suku bunga obligasi lebih menarik, maka obligasi ini akan ditawarkan dengan premium, sehingga harga obligasi akan meningkat. Sebaliknya dari sisi investor penjual obligasi akan mengalami kerugian suku bunga yang lebih rendah kalau hasil penjualan obligasi dimasukkan ke tabungan. Investor mau menjual obligasinya dengan premium untuk mengkompensasi kerugian suku bunganya. Hasil penelitian ini sejalan dengan penelitian yang dilakukan oleh Longstaff dan Schwartz (1993), Sukanto (2009), Juhartono (2010), Haryanto (2013) dan Dewi, dkk (2016).

Hipotesis ketiga dalam penelitian ini menyatakan bahwa kurs berpengaruh negatif signifikan terhadap harga obligasi. Berdasarkan hasil pengujian hipotesis, diketahui bahwa nilai koefisien kurs $-0,324$ dan signifikansi sebesar 0,020 lebih kecil dari $\alpha=0,05$. Hal ini menunjukkan bahwa $\mathrm{H}_{3}$ diterima. Nilai tukar rupiah terhadap dollar (kurs) dan harga obligasi memiliki hubungan negatif dan signifikan dengan nilai 32,4 persen. Artinya ketika kurs mengalami kenaikan atau penurunan akan diikuti penurunan atau kenaikan harga obligasi.

Hasil penelitian ini menunjukkan bahwa nilai tukar rupiah terhadap dollar (kurs) dapat memicu oleh sentimen positif bagi pelaku pasar. Kemudian terjaganya kurs 
Rupiah terhadap USD yang terapresiasi merupakan faktor pendukung positifnya pasar obligasi domestik. Diterimanya hipotesis mendukung teori yang dikemukakan oleh Husnan (2009) yang menyatakan nilai tukar rupiah terhadap mata uang lainnya sangat berpengaruh bagi perusahaan yang ingin melakukan investasi, karena apabila pasar valuta asing lebih menarik daripada pasar modal maka investor akan beralih kepada pasar valuta asing, sehingga perubahan nilai tukar akan berpengaruh terhadap harga pasar obligasi di pasar modal.

Dalam sisi lain dengan adanya ekspektasi kurs yang positif tersebut membuat nilai perusahaan akan mengalami kenaikan sehingga terjadi peningkatan harga sekuritas (saham dan obligasi). Sebaliknya jika suku bunga naik, beban biaya modal dan operational cost akan naik sehingga pendapatan operasional (EBIT) dari emiten akan turun yang akan tercermin pada penurunan harga sekuritas baik saham dan obligasi. Hasil penelitian ini sejalan dengan penelitian yang dilakukan oleh Sukanto (2009), Hadian (2013), Haryanto (2013) dan Dewi, dkk (2016).

Hipotesis keempat dalam penelitian ini menyatakan bahwa coupon rate berpengaruh positif signifikan terhadap harga obligasi. Berdasarkan hasil pengujian hipotesis, diketahui bahwa nilai koefisien coupon rate $-0,438$ dan signifikansi sebesar 0,001 lebih kecil dari $\alpha=0,05$. Hal ini menunjukkan bahwa $\mathrm{H}_{4}$ ditolak. coupon rate dan harga obligasi memiliki hubungan yang kuat dan signifikan, dengan nilai sebesar 43,8 persen. Artinya ketika coupon penurunan nilai akan diikuti penurunan harga obligasi. Hasil penelitian ini tidak sesuai dengan hipotesis yang diajukan, namun sesuai dengan hasil penelitian yang dilakukan oleh Purba (2016) yang menyatakan kupon obligasi berpengaruh negatif signifikan terhadap harga obligasi.

Hasil penelitian ini mengisyaratkan bahwa para investor atau calon pembeli obligasi Surat Utang Negara perlu memperhatikan faktor coupon rate yang mempengaruhi harga obligasi. Hal ini dapat dimengerti karena emiten (issuer) yang memperdagangkan atau pada saat lelang obligasi, menjual obligasi dengan nilai coupon rate yang kecil atau hampir sama besarnya dengan tingkat suku bunga SBI yang berlaku pada saat obligasi dijual atau dilelang. Raharjo (2003) menyatakan nilai kupon obligasi yang diberikan cukup kecil, maka harga obligasi tersebut akan cenderung turun karena daya tarik untuk investor atau calon pembeli obligasi tersebut sangat sedikit.

Hipotesis kelima dalam penelitian ini menyatakan bahwa likuiditas obligasi berpengaruh positif signifikan terhadap harga obligasi. Berdasarkan hasil pengujian hipotesis, diketahui bahwa nilai koefisien likuiditas obligasi 0,016 dan signifikansi sebesar 0,927 lebih besar dari $\alpha=0,05$. Hal ini menunjukkan bahwa $\mathrm{H}_{5}$ ditolak. Likuditas obligasi tidak dapat mempengaruhi naik atau turunnya harga obligasi, disebabkan memiliki hubungan yang sangat kecil sebesar 0,16 persen. Nilai koefisien likuditas obligasi positif, namun likuiditas obligasi belum cukup berperan dalam menentukan kenaikan atau penurunan harga obligasi.

Salah satu alasan yang dapat disebutkan bahwa tidak ada pengaruh likuiditas obligasi terhadap harga obligasi karena tujuan diterbitkannya Surat Utang Negara adalah untuk menutupi defisit APBN dan menggalang dana masyarakat sehingga pada saat jatuh tempo, investor atau pembeli obligasi tidak merasa rugi terhadap risiko gagal bayar (default risk) karena pemerintah dapat menjamin adanya risiko gagal bayar tersebut atau pemerintah dapat menerbitkan Surat Utang Negara baru. Hasil penelitian 
ini mengisyaratkan kepada para investor bahwa likuiditas obligasi khususnya obligasi pemerintah RI (Surat Utang Negara) bukan merupakan faktor yang utama dalam menentukan fluktuasi harga obligasi, tingginya transaksi dan volume obligasi tergantung dari hasil lelang obligasi atau obligasi yang dijual memiliki tenor pendek atau panjang. Hasil penelitian ini tidak sejalan dengan penelitian yang dilakukan oleh Krisnilasari (2007) Penelitian Daryono (2016). Hasil penelitian Chakravarty dan Sarkar (1999), Yuan (2001) dan Facero et.al (2008). Hasil penelitian dari Elton dan Green (1998) Kempf dan Homburg (2000), Kesumawati (2003), Syafridi (2006).

\section{KESIMPULAN}

Penelitian ini diperoleh: 1).Inflasi berpengaruh positif tapi tidak signifikan terhadap harga obligasi Pemerintah RI (Surat Utang Negara). Artinya peningkatan atau penurunan inflasi tidak dapat diikuti penurunan atau peningkatan harga obligasi. 2).Suku bunga berpengaruh negatif signifikan terhadap harga obligasi Pemerintah RI (Surat Utang Negara). Artinya ketika suku bunga mengalami kenaikan, maka akan diikuti penurunan harga obligasi. 3).Kurs berpengaruh negatif signifikan terhadap harga obligasi Pemerintah RI (Surat Utang Negara). Artinya ketika kurs Rupiah terhadap Dollar mengalami kenaikan, maka akan diikuti penurunan harga obligasi. 4).Coupon rate berpengaruh negatif signifikan terhadap harga obligasi Pemerintah RI (Surat Utang Negara). Artinya penurunan coupon rate akan diikuti penurunan harga obligasi. 5).Likuiditas obligasi berpengaruh positif tapi tidak signifikan terhadap harga obligasi Pemerintah RI (Surat Utang Negara). Artinya ketika obligasi memiliki likuiditas tinggi atau rendah tidak dapat diikuti peningkatan atau penurunan harga obligasi. Rekomendasi peneliti berupa 1).Bagi investor sebelum memutuskan untuk membeli obligasi, agar lebih memperhatikan faktor-faktor yang dapat mempengaruhi harga obligasi, terutama faktor makro ekonomi (inflasi, suku bunga, dan kurs) yang selalu berfluktuasi, serta faktor dari karakteristik obligasi seperti coupon rate (bunga obligasi) dan likuiditas obligasi. 2).Selain itu, ketika ingin membeli obligasi, sebaiknya memilih obligasi yang memberikan coupon rate (bunga obligasi) yang lebih tinggi dengan nilai kupon yang tinggi akan memberikan yield yang makin tinggi, karena dari hasil penelitian menyatakan bahwa coupon rate berpengaruh negatif terhadap harga obligasi.

\section{UCAPAN TERIMA KASIH}

Penulis mengucapkan terima kasih kepada Lembaga Penelitian dan Pengabdian

Kepada Masyarakat (LPPM), Universitas Muhammadiyah Kendari yang telah memberikan dukungan financial dalam penelitian ini.

\section{DAFTAR PUSTAKA}

Ahmad N dan Greace S. (2007). Pengaruh Rating dan Kupon Terhadap Harga Obligasi Studi Kasus Obligasi Kriterian Investasi Yang Terdaftar di BES 2002-2006. Jurnal Ilmiah Vol.7 No.1 pp:101-110.

Amihud, Yakov dan Haim Mendelson. (1991). Liquidity, Maturity, and Yield on US Treasury Securities. The Journal of Finance, 46(4), pp:1411-1425. 
Anang, AR dan Sam'ani. (2007). Analisis Faktor-Faktor Yang Mempengaruhi Yield Obligasi Negara Tahun 2010-2012. Jurnal Ekonomi Manajemen Akuntansi No.35.

Baele, L, Bekaert G, et.,al. (2007). The Determinants of Stock and Bond Return Comovement. Working Paper Research No.119 National Bank of Belgium.

Brigham dan Houston. 2006. Dasar-Dasar Manajemen Keuangan, Buku Satu, Edisi Sepuluh. Jakarta: Salemba Empat.

Bodie, Zvi; Kane, Alex; Markus, Alan J. (2001). Investments, McGraww-Hill, New York.

Boediono. (1996). Seri Sinopsis Pengantar Ilmu Ekonomi No. 5: Ekonomi Moneter BPFE, Yogyakarta.

(2009), Seri Sinopsis Pengantar Ilmu Ekonomi. Ekonomi Moneter, Yogyakarta, BPFE.

Chakravarty, S dan Sarkar A. (1999). Liquidity In US Fixed Income Markets: A Comparison Of The Bid-Ask Spread In Corporate, Government and Municipal Bond Markets. SSRN Working Paper.

Damena, Herdy dkk. (2013). Analisis Pengaruh Coupon (Bunga Obligasi), Jangka Waktu Jatuh Tempo dan Likuiditas Obligasi Terhadap Tingkat Perubahan Harga Obligasi Yang Terdaftar di BEI. Jurnal Manajemen \& Keuangan Vol 6 Nomor 2 (Agustus 2013).

Daryono Soebagiyo. (2016). Determinan Surat Utang Negara (SUN) dengan Pendekatan ECM. Universty Research Colloquium. ISSN 2407-9189.

Dewi Kusuma Ni Putu Giri, dkk. (2016). Pengaruh Suku Bunga, Nilai Tukar, Coupon Rate dan Likuiditas Obligasi Terhadap Harga Pasar Obligasi Pada Sektor Keuangan. Jurnal Manajemen Unud ,Vol.5,No.5, 2016.

Elton, Edwin J dan T Clfton Green. (1998). Tax and Liquidity Effect in Pricing Government Bonds. The Journal of Finance, 53 (5), pp: 1533-1562.

Fabozzi, F.J. (2004). Bond Markets, Analysis, and Strategies. Fifth Edition. Upper Saddle River, New Jersey: Pearson Education, Inc.

Fabella, R., \& Madhur, S. (2003). Bond market development in East Asia: Issues and challenges. ERD Working Paper No.35.

Facero, Pagano dan Thadden. (2008). How Does Liquidity Affect Government Bond Yield. Journal of Financial and Quantitative Analysis, 45 pp; 107-134.

Fitriana, Eka Sari \& Rohayati Suci. (2013). Pengaruh Suku Bunga Terhadap Harga Obligasi Melalui Yield Obligasi. Jurnal Ilmu Manajemen Vol.1 No.3 Mei 2013.

Geetha, C Mohidin, R. (2011). The Relationship Between Inflation and Stock Market: Evidence From Malaysia, USA and China. International Journal of Economic and Management, 1 (2); 1-16.

Ghozali Imam, 2011. Aplikasi Analisis Multivariate Dengan Program SPSS, Edisi Ketiga. Semarang: Badan Penerbit Universitas Diponegoro.

Hadian, Niki. (2013). Influence on Obligation Level Changes, Interest Rate, SBI, Growing $P D B$, Exchange Rate Rupiah-USD, and Inflation Towards Change of Cooperation Obligation Price that Listing on PT BEI for Period 2002-2007. Jurnal Fakultas Ekonomi Universitas Widyatma. 
Haryanto, Muhammad Arif. (2013). Analisis Pengaruh Maturity, Tingkat Suku Bunga SBI, Kurs dan Harga Minyak Dunia Terhadap Harga Obligasi Pemerintah. Jurnal Ekonomi dan Bisnis.

Henderson, BJ, et.,al. (2004). Word Markets For Raising New Capital. Journal Of Financial Economic, 82: 63-102.

Husnan, Suad. (2003). Dasar-Dasar Teori Portofolio dan Analisis Sekuritas Edisi Ketiga. Yogyakarta: Unit Penerbit dan Percetakan Sekolah Tinggi Ilmu Manajemen YKPN.

(2009). Dasar-dasar Teori Portofolio dan Analisis Sekuritas Edisi Keempat. Yogyakarta: Unit Penerbit dan Percetakan Sekolah Tinggi Ilmu Manajemen YKPN.

Hutabarat, A.R. (2005). Determinan Inflasi Indonesia. Occasional Paper No OP/06/2005. Bank Indonesia.

Ichsan, dkk. (2013). Dampak BI Rate, Tingkat Suku Bunga, Nilai Tukar Rupiah dan Inflasi Terhadap Nilai Obligasi Pemerintah. Jurnal Keuangan dan Perbankan.

I Made Adi Saputra. (2016). Mencermati Pergerakan harga SUN. Analis fixed income PT MNC Securities.

Indarsih, Nanik. (2013). Pengaruh Tingkat Suku Bunga SBI, Rating, Likuiditas dan Maturitas terhadap Yield to Maturity Obligasi. Jurnal IImu Manajemen, 1(1), pp:125-136.

Jogiyanto, Hartono. (2009). Teori Portofolio dan Analisis Investasi. Yogyakarta: BPFE UGM.

Kadir, Syamsir. (2007). Pengaruh Faktor Struktural dan Fundamental Ekonomi Terhadap Harga Obligasi Korporasi di Pasar Modal Indonesia. Desertasi Program Doktor Ilmu Ekonomi: UNPAD.

Kempf dan Homburg. (2000). Liquidity and Its Impact on Bond Prices. Schmalenbach Business Reviews, 52, pp: 26-44.

Kesumawati. (2003). Pengaruh Tingkat Utang dan Berbagai Faktor Yang Turut Mempengaruhi Harga Obligasi Sebagai Variabel Kontrol Terhadap Yield Premium Obligasi. Tesis Magister Manajemen UKSW Salatiga.

Kewal, S.S. (2012). Pengaruh Inflasi, Suku Bunga, Kurs dan Pertumbuhan PDB Terhadap Indek Harga Saham Gabungan. Jurnal Economia, 8 (1): 53-61.

Krisnilasari M. (2007). Analisis Pengaruh Likuiditas Obligasi, Coupon dan Jangka Waktu Terhadap Perubahan Harga Obligasi di Bursa Efek Surabaya. Tesis Magister Manajemen UNDIP.

Kurniasih Augustina \& Restika Yulia. (2015). The influence of Macroeconomic Indicators and Foreign Ownership on Government Bond Yields: A Case of Indonesia. Mediterranean Journal of Social Sciences MCSER Publishing, Rome-Italy Vol. 6 No 5 S5. ISSN 2039-2117.

Longstaff, Francis A dan Eduardo S. Schwartz. (1993). Interest Rate Volatility and Bond Pricees. Financial Analyst Journal. 49, pp :70-74.

Mardika Ekawati, Eirene. (2008). Pengaruh Kupon Obligasi dan Yield Obligasi Terhadap Harga Pemerintah Seri Fixed Rate Periode 2005-2006. Jurnal Penelitian. 
Miskhin, Frederic S. (2008). The Economics of Money, Banking, and Financial Market Ekonomi Uang, Perbankan, dan Pasar Keuangan. Buku 1, Edisi 8. Jakarta: Penerbit Salemba Empat.

Nurfauziah dan Adistien. (2004). Analisis Faktor-Faktor Yang Mempengaruhi Yield Obligasi Perusahaan (Studi Kasus Pada Industri Perbankan dan Industri Finansial). Jurnal Siasat Bisnis, 2 (9), pp:241-256.

Ogawa, E \& Shimizu, J. (2004). Bond Issuers Trade Of For Common Curency Basket Denominated Bond In East Asia. Journal Of Asian Economic, 15 : 719-738.

Pohan, Aulia. (2008). Potret Kebijakan Moneter Indonesia, Cetakan Pertama. Jakarta, PT Raja Grafindo.

Purba, Afrida. (2016). Analisis Pengaruh Likuiditas Obligasi, Waktu Jatuh Tempo Dan Kupon Obligasi Terhadap Harga Obligasi Korporasi di Bursa Efek Indonesia (Bei). Jurnal Fakultas Ekonomi Dan Bisnis Universitas Lampung Bandar Lampung.

Puspita, W.A. \& Haryono, A. (2012). Analisis Pengaruh Suku Bunga SBI terhadap Nilai Emisi Obligasi baik dalam Jangka Pendek maupun Jangka Panjang di Pasar Modal Indonesia Periode Tahun 2007-2009. Jurnal Ekonomi dan Studi Pembangunan, 4(1): 105-112.

Putong, Iskandar. (2002). Pengantar Ilmu Ekonomi Mikro dan Makro, penerbit ghalia indonesia, Jakarta.

Raharjo, Sapto. (2003). Panduan Investasi Obligasi. Jakarta: Gramedia Pustaka Utama.

Racette, GA dan WG. Lawelen, 1995. Corporate Debt Coupon Strategies. National Tax Journal, 29, pp: 165-177.

Robbert Ang. (1997). Pasar Modal Indonesia. Jakarta: Mediasoft Indonesia.

Sudirman, Wayan. (2011). Kebijakan Fiskal dan Moneter Teori dan Empirikal. Jakarta: Kencana Prenada Media Group.

Sukanto Eman. (2009). Pengaruh Suku Bunga Deposito, Kurs Rupiah US, Tingkat Inflasi, IHSG dan Volume Transaksi Terhadap Harga Obligasi Pemerintah (SUN). Jurnal Fokus Ekonomi Vol.4 No.2 Desember 2009.

Sukanto Eman dan Widaryanti. (2015). Pengaruh Suku Bunga Deposito, Kurs Rupiah Tingkat Inflasi, Terhadap Harga Obligasi Pemerintah (SUN). Jurnal Dinamika dan Ekonomi Vol.4 No.2 Desember 2009.

Sunaryah. (2011). Pengantar Pengetahuan Pasar Modal. Yogyakarta: UPP STIM YKPN. Sugiyono. (2012). Metode Penelitian Kombinasi. Cetakan ketiga. Bandung: Alfabeta.

Syafridy R. Hartanto. (2006). Pengaruh Suku Bunga, Inflasi, Kurs Rupiah, IHSG, Kinerja Perusahaan dan Likuiditas Perusahaan Terhadap Perubahan Harga Obligasi Syariah di Pasar Sekunder (Studi Kasus Obligasi Indosat Syariah Mudharabah, 2002). Tesis Magister Sains Keuangan Syariah UII.

Sri Handaru Yuliati, et.,al. (1996). Manajemen Portofolio dan Analisis Investasi. Yogyakarta: Andi Ofset.

Tandelilin. E. (2010). Portofolio dan Investasi. Edisi 1. Yogyakarta: Penerbit Kanisius.

Valckx, Nico. (2004). The Decomposition Of US and Euro Area Stock and Bond Returns and Their Sensitifity to Economic State Variables. The European Journal Of Finance, 10, pp: 149-173.

Yuan, Kathy. (2001). The Liquidity Service Of Sovereign Bond. Working Paper. 